\title{
Water Quality at Wildlife Water Sources in the Sonoran Desert, United States
}

\author{
Steven S. Rosenstock, ${ }^{1}$ Vernon C. Bleich, ${ }^{2}$ \\ Michael J. Rabe, ${ }^{3}$ and Carlos Reggiardo ${ }^{4}$

\begin{abstract}
Authors are ${ }^{1}$ Research Program Supervisor, Arizona Game and Fish Department, Research Branch, Phoenix, AZ 85023; Bishop, CA 93514; ${ }^{3}$ Migratory Bird Program Supervisor, Arizona Game and Fish Department, Game Branch, Phoenix, AZ 85023; and ${ }^{4}$ Research Scientist, University of Arizona, Veterinary Diagnostic Lab, Tucson, AZ 85705.
\end{abstract} \\ ${ }^{2}$ Senior Environmental Scientist, Sierra Nevada Bighorn Sheep Recovery Program, California Department of Fish and Game,
}

\begin{abstract}
Surface water is an important limiting factor for wildlife populations in desert environments where water sources are uncommon or have been lost or degraded due to human activities. To address this need, wildlife water developments have been constructed in many areas of the southwestern United States, particularly in the Sonoran Desert. Previous studies of wildlife water developments are limited and critics have asserted that water quality at these facilities may be deleterious to animal health. Water quality was evaluated at natural, modified natural, and constructed water sources in the Sonoran Desert of southwestern Arizona and southeastern California. Samples were taken from primary sources of surface water available to wildlife, including natural tinajas (rock basins), modified tinajas, springs, rainwater catchments ("guzzlers"), and wells. Water samples were tested for 21 chemical constituents known to affect animal health, blue-green algal toxins, and a presumed waterborne pathogen, the protozoan avian parasite Trichomonas gallinae. Seven chemical constituents were absent or below detection limits. The majority of constituents detected (10/13, 77\%) occurred at levels below recommended guidelines for domestic animals. Elevated pH, alkalinity, and fluoride were found in rainwater catchments, springs, and wells, respectively, but at relatively low levels unlikely to affect animal health. Blue-green algal toxins were not detected and there was no evidence of Trichomonas. Although specific water quality guidelines for wildlife are lacking, these results do not support hypothesized negative impacts to wildlife populations from developed water sources.
\end{abstract}

\section{Resumen}

El agua superficial es un factor limitante importante para las poblaciones de fauna silvestre de los ambientes desérticos, donde las fuentes de agua son poco comunes o se han perdido o degradado debido a las actividades humanas. Para resolver esta necesidad se han construido aguajes para la fauna silvestre en muchas áreas del suroeste de Estados Unidos de América, particularmente en el Desierto Sonorense. Estudios previos acerca de este tema son limitados y los críticos han declarado que la calidad del agua en estos aguajes pude ser perjudicial para la salud animal. La calidad del agua se evaluó en aguajes naturales, naturales modificados y construidos por el hombre en el Desierto Sonorense en el suroeste de Arizona y sudeste de California. Las muestras fueron tomadas de fuentes primarias de agua superficial disponibles para la fauna silvestre, incluyendo tinajas naturales (cunecas de roca), tinajas modificadas, manantiales, capturas de agua de lluvia (“guzzlers”) y pozos. En las muestras de agua se evaluaron: 21 constituyentes químicos que se sabe afectan la salud animal, toxinas de algas azul-verde y un patógeno, que se presume es acarreado por el agua, el protozoario parásito de las aves Trichomonas gallinae. Siete de los constituyentes estuvieron ausentes o abajo de los limites de detección. La mayoría de los constituyentes detectados (10/13, 77\%) estuvieron en niveles abajo de los recomendados para animales domésticos. En un tipo de fuente de agua se encontró pH elevado, alcalinidad y fluorfuro, pero en niveles relativamente bajos que es improbable que afecten la salud animal. No se detectaron toxinas de algas azul-verde ni evidencia de Trichomonas. En tanto se crezca de lineamientos específicos de la calidad del agua para la fauna silvestre, estos resultados no sostienen las hipótesis de los impactos negativos para las poblaciones de fauna silvestre por efecto de los aguajes construidos para ellas. El diseño de aguajes y las prácticas de mantenimiento son recomendadas para mejorar la calidad del agua.

Key Words: guzzlers, tinajas, waterborne pathogens, chemical parameters, blue-green algal toxins, Trichomonas

\section{INTRODUCTION}

Research was supported by Pittman-Robertson Federal Aid in Wildlife Restoration State Trust Grant to the Arizona Game and Fish Dept, Project W-78-R, funds provided by the US Army Yuma Proving Ground Conservation Program, and the California Dept of Fish and Game Mountain Sheep Conservation Program. This is Professional Paper 036 from the Eastern Sierra Center for Applied Population Ecology.

Correspondence: Steven Rosenstock, Arizona Game and Fish Department, Research Branch/WMRS, 2221 W Greenway Rd, Phoenix, AZ 85023. Email: srose@azgfd.gov

Manuscript received 17 September 2004; manuscript accepted 6 August 2005.
Resource managers have long assumed that water is a primary limiting factor for wildlife populations in desert environments. Beginning in the 1940s, state and federal resource management agencies initiated water development programs intended to benefit game species and other wildlife. Many of those programs are ongoing and $>1000$ wildlife water developments have been built and maintained in the Sonoran, Mojave, 
and Chihuahuan deserts of the southwestern United States (Rosenstock et al. 1999).

Water quality at developed sources has received little previous study and has emerged as an issue in the ongoing debate over benefits and impacts of wildlife waters (Rosenstock et al. 1999). Particularly during hot summer months, surface waters have characteristics that can affect water quality, including high water temperatures, high evaporation rates, inputs of organic material, and infrequent flushing. Critics of water development programs have suggested that high levels of minerals, chemical toxins, toxic blooms of blue-green algae, and waterborne pathogens may be present in wildlife waters, resulting in adverse impacts to wildlife populations (Kubly 1990; Broyles 1995).

The overall goal of this study was to assess water quality at natural, modified natural, and constructed water sources in the Sonoran Desert of southwestern Arizona and southeastern California, an area where such developments are an important but controversial element of wildlife conservation programs. Our specific objectives were to determine levels of chemical constituents and blue-green algal toxins that can affect wildlife health, and to quantify the frequency of occurrence of the protozoan parasite (Trichomonas gallinae) that causes trichomoniasis in wild birds. We tested hypotheses that water quality parameters would be within published animal health guidelines and that occurrence of Trichomonas would vary among different types of water sources.

\section{METHODS}

\section{Study Area}

The study was conducted on the Yuma Proving Ground, the Kofa National Wildlife Refuge, and adjacent Bureau of Land Management (BLM) lands in southwestern Arizona, and on the Chocolate Mountains Aerial Gunnery Range and adjacent BLM lands in southeastern California. The Arizona portion of the study area encompassed about $8000 \mathrm{~km}^{2}$, the California portion about $6000 \mathrm{~km}^{2}$. Topography is diverse, consisting of rugged mountain ranges, bajadas, broad valleys, and dry washes. Dominant plant communities are Sonoran Desertscrub, Lower Colorado River Valley, and Arizona Upland subdivisions (Brown 1994). Elevations range from $20 \mathrm{~m}$ in lower valleys to $1467 \mathrm{~m}$ in montane areas. Long-term average precipitation at the 5 nearest weather stations is as follows: $93 \mathrm{~mm}$ (Yuma Proving Ground, Arizona, $105 \mathrm{~m}$ elevation), $173 \mathrm{~mm}$ (Kofa Mine, Arizona, $584 \mathrm{~m}$ elevation), $97 \mathrm{~mm}$ (Blythe, California, $86 \mathrm{~m}$ elevation), $65 \mathrm{~mm}$ (Imperial, California, $20 \mathrm{~m}$ elevation), and $67 \mathrm{~mm}$ (Brawley, California, $39 \mathrm{~m}$ elevation). The following mean daily minimum (January) and daily maximum (July) temperatures $\left({ }^{\circ} \mathrm{C}\right)$ have been measured: Yuma Proving Ground $(6.3,41.4)$, Kofa Mine $(8.0,39.8)$, Blythe (3.4, 42.4), Imperial $(5.6,41.2)$, and Brawley $(4.0,42.1)$ (Western Regional Climate Center 2004). A large portion of the study area (Yuma Proving Ground and Chocolate Mountains Aerial Gunnery Range) is used for military research and training activities and is closed to public access. Open portions of the Proving Ground, Kofa Refuge, and BLM lands in Arizona and California receive relatively little human visitation; visitation is primarily by hunters, hikers, and off-road vehicle users.
Domestic livestock have been excluded from the study area for $>20$ years, but feral donkeys (Equus asinus L.) and feral horses (Equus caballus L.) are present. Naturally occurring surface water is scarce across most of the study area, consisting of a few perennial springs, mostly ephemeral rock pools (tinajas), and short-duration flows in washes following major rainfall events. To increase availability of water for game and nongame wildlife, $>200$ water developments have been built by land managers and sportsmen's groups.

A cluster sampling approach (Schaefer et al. 1979) was used to select 45 sites representing surface water sources utilized by wildlife on both study areas. Water sources included natural tinajas (rock basins), modified tinajas, springs, rainwater catchments ("guzzlers"), and wells. Water types were sampled in approximate proportion to their availability on the study area, resulting in small sample sizes for some types (e.g., springs and wells) that were few in number or difficult to access for research purposes. Tinajas $(n=23)$ were located in canyons and rocky drainages, 14 were unmodified natural tanks and 9 had been modified by addition of masonry dams, diversions, or gabions that increased inflow and storage capacity and reduced sedimentation (Halloran and Deming 1958; Werner 1985). Surface area of tinajas varied $\left(6-80 \mathrm{~m}^{2}\right.$ surface area at full capacity) and fluctuated with evaporation and inflow events. All springs $(n=3)$ were developed and located in upland areas. Two springs consisted of buried concrete basins of $6-10 \mathrm{~m}^{2}$ surface area that collected subsurface flow from perched water tables, the third spring collected surface flow $\left(\mathrm{ca} .2 \mathrm{~L} \cdot \mathrm{min}^{-1}\right)$ in a concrete box and piped it to a concrete trough. Rainwater catchments $(n=16)$ were located on bajadas or in valley bottoms adjacent to large washes. These systems collected rainwater from a natural surface or metal apron, stored the water in a metal, concrete or fiberglass tank, and dispensed it via a concrete or fiberglass trough (Wright 1959; Gunn 1990; Lesicka and Hervert 1995). Wells $(n=3)$ were shallow $(<40 \mathrm{~m}$ total depth), located along major washes, and operated by windmills. Pumped water was stored in an aboveground metal or fiberglass tank and dispensed via a concrete drinking trough. All water developments except ephemeral tinajas held water for the duration of data collection. Some rainwater catchments had previously received water hauled from nearby agricultural or municipal wells when recharge from natural precipitation was insufficient to meet wildlife demands. All water developments in areas occupied by feral equines or domestic livestock were fenced to exclude those animals.

\section{Chemical Parameters}

Arizona water samples were collected in March 2000, August 2000, January 2001, and April 2001; California samples were collected in May and October 1998. Samples were $1 \mathrm{~L}$ in volume and taken from the top $10 \mathrm{~cm}$ of water at points where animals gained access to drink. Samples were analyzed for 21 chemical parameters: arsenic, barium, cadmium, calcium, chloride, chromium, copper, fluoride, iron, lead, mercury, nitrate (as N), nitrite, selenium, silver, sulfate, sulfide, zinc, alkalinity (as $\mathrm{CaCO}_{3}$ ), $\mathrm{pH}$, and total dissolved solids (TDS). Analyses were done by certified labs in Arizona (Turner Labs Inc, Tucson, AZ) and California (Department of Fish and Game Water Pollution Studies Laboratory, Rancho Cordova, Marine Pollution Studies 
Laboratory, Moss Landing, CA) following standard procedures (Clesceri et al. 1998). Because recommendations for wildlife water quality are lacking, measured values of chemical parameters were evaluated using published guidelines for domestic poultry, cattle, sheep, and horses (Peterson 1999). For each parameter, a 95\% confidence interval (CI) was calculated around measured values for each development type. Results were considered significant if the upper bound of the confidence interval was greater than or equal to the guideline value.

\section{Blue-green Algal Toxins}

Monthly tests for blue-green algal toxins were done from April through October during the years from 2001 to 2003 at wildlife waters in Arizona. When algal blooms were present, a $500-\mathrm{mL}$ composite sample was collected from multiple points where animals gained access to drink. Samples were kept on ice during transportation to the laboratory and then refrigerated at $4^{\circ} \mathrm{C}$ until analysis. An enzyme-linked immunoassay (ELISA) test (\#ET-022, Envirologix, Inc, Portland, ME) was used to detect 4 variants of microcystin (LR, LA, RR, and YR) and nodularin toxins. The limit of detection was $0.3 \mu \mathrm{g} \cdot \mathrm{L}^{-1}$.

\section{Waterborne Pathogens}

Monthly water samples from Arizona wildlife waters were screened for the protozoan parasite Trichomonas gallinae. Samples were collected from April to October during 2002 and 2003, taking a composite 500-mL sample at multiple points at each site where animals gained access to drink. Samples were stored on ice after collection and then refrigerated at $4^{\circ} \mathrm{C}$ until analysis. Before culturing, algae and debris were removed by filtering through No. 1 filter paper (\#1001240, Whatman, Inc, Clifton, NJ). Three InPouch ${ }^{\mathrm{TM}}$ TF test pouches (BioMed Diagnostics, San Jose, CA) were inoculated with $0.5-\mathrm{mL}$ aliquots from each clarified water sample. Pouches were incubated at $37^{\circ} \mathrm{C}$ for 3 days and examined daily under a microscope for presence of trichomonads (motile protozoans).

\section{RESULTS AND DISCUSSION}

\section{Chemical Parameters}

Seven constituents of potential concern were absent from all water samples (below analytic detection limits, in parentheses): barium $\left(0.1 \mathrm{mg} \cdot \mathrm{L}^{-1}\right)$, cadmium $\left(0.003 \mathrm{mg} \cdot \mathrm{L}^{-1}\right)$, chromium $\left(0.03 \mathrm{mg} \cdot \mathrm{L}^{-1}\right)$, copper $\left(0.02 \mathrm{mg} \cdot \mathrm{L}^{-1}\right)$, mercury $(0.001$ $\left.\mathrm{mg} \cdot \mathrm{L}^{-1}\right)$, selenium $\left(0.005 \mathrm{mg} \cdot \mathrm{L}^{-1}\right)$, and silver $\left(0.01 \mathrm{mg} \cdot \mathrm{L}^{-1}\right)$. The majority of constituents detected $(10 / 13,77 \%)$ occurred at levels below recommended guidelines for domestic animals (Table 1). Three parameters occurred at significant levels, each exceeding recommended guidelines in one type of water source (Table 1). Values of $\mathrm{pH}$ exceeded the guideline of 8.5 at rainwater catchments (upper bound of $95 \% \mathrm{CI}=8.8$ ). Alkalinity exceeded the $500 \mathrm{mg} \cdot \mathrm{L}^{-1}$ guideline at springs (upper bound of $95 \% \mathrm{CI}=563$ ). Fluoride exceeded the $2 \mathrm{mg} \cdot \mathrm{L}^{-1}$ guideline at wells (upper bound of $95 \% \mathrm{CI}=2.7$ ). However, these elevated levels were likely of minimal concern from an animal health standpoint. Peterson (1999) noted that high pH values could reduce chlorination efficiency, which is not a factor in wildland water sources that are not treated. Peterson (1999) indicated that excess alkalinity can have a laxative effect and that excess fluoride may cause mottling of teeth.

The little published information on water quality at wildlife waters primarily consists of measurements of parameters such as $\mathrm{pH}$ and TDS that are easily measured in the field. Observed values in the present study were very similar to those reported previously from other wildlife water developments in southwestern Arizona deserts (deVos and Clarkson 1990; Kubly 1990; Schmidt and DeStefano 1999).

\section{Blue-green Algal Toxins}

A total of 211 water samples were screened for microcystin and nodularin: 112 from precipitation catchments, 64 from tinajas, 30 from springs, and 5 from wells. All ELISA tests were negative $\left(<0.3 \mu \mathrm{g} \cdot \mathrm{L}^{-1}\right.$ detection threshold). Blue-green algae are widely distributed in desert soils and aquatic environments in North America (Shields and Drouet 1962; Fletchner et al. 1998; Shephard et al. 2000) and are present in wildlife water sources in southwestern Arizona (S. Rosenstock, unpublished data, 2004). The lack of detectable toxins suggests that toxinproducing species or strains were absent, or that wildlife waters did not provide suitable conditions for toxic blooms. Animal poisonings typically occur on lakes and other large water bodies (Schwimmer and Schwimmer 1968) that have nearpermanent summer standing crops of blue-green algae (Codd and Bell 1985), when wind drift concentrates surface scum and associated toxins (Pybus et al. 1986; Ressom et al. 1994). Such conditions did not occur at the small water sources sampled in this study, where blooms were short-lived and surface scums were rare.

\section{Waterborne Pathogens}

A total of 189 water samples were cultured for Trichomonas: 116 from precipitation catchments, 65 from tinajas, and 8 from springs. All cultures were negative; however, there were no reported outbreaks of avian trichomoniasis in southwestern Arizona during the study. Cultures from similar rainwater catchments in west-central Arizona where sick and dying mourning doves (Zenaida macroura) were found during a 2003 trichomoniasis outbreak were also negative (S. Rosenstock, unpublished data, 2004). The organism is killed by exposure to UV radiation (Hedlund 1996) and maximum survival time in water was estimated at 2 to 24 hours (Kocan 1969). When water from rainwater catchments on the study area was inoculated with live trichomonads, follow-up cultures were negative after 24 hours (C. Reggiardo, unpublished data, 2004). These results suggest that wildlife water sources like those included in this study do not provide suitable environments for persistence and transmission of Trichomonas.

\section{CONCLUSIONS AND MANAGEMENT IMPLICATIONS}

Results of this study do not support hypothesized water quality problems cited by critics of water development programs. Although specific guidelines for wildlife are lacking, water quality was similar at natural, modified natural, and constructed water sources and was unlikely to adversely affect 
Table 1. Recommended guidelines (Peterson 1999) and measured values of water quality parameters at 5 different types of wildlife water sources in the Sonoran Desert, southwestern Arizona and southeastern California. All values are $\mathrm{mg} \cdot \mathrm{L}^{-1}$ except $\mathrm{pH}$ (units). Bolded upper confidence interval (Cl) values exceed recommended guideline (Peterson 1999).

\begin{tabular}{|c|c|c|c|c|}
\hline $\begin{array}{l}\text { Parameter } \\
\text { (Guideline) }\end{array}$ & Water type & Range & Mean & $\begin{array}{l}\text { Upper } \\
95 \% \mathrm{Cl}\end{array}$ \\
\hline $\mathrm{pH}$ & Natural tinaja & $7.2-12.0$ & 8.06 & 8.28 \\
\hline \multirow[t]{4}{*}{ (8.5) } & Modified tinaja & $7.0-9.0$ & 7.89 & 8.12 \\
\hline & Catchment & $7.1-12.0$ & 8.49 & 8.84 \\
\hline & Spring & $7.1-8.7$ & 7.97 & 8.37 \\
\hline & Well & $7.6-9.1$ & 8.22 & 8.46 \\
\hline TDS & Natural tinaja & $74-1756$ & 265.68 & 423.45 \\
\hline \multirow[t]{4}{*}{$(3000)$} & Modified tinaja & $34-440$ & 205.52 & 250.33 \\
\hline & Catchment & $56-1700$ & 402.65 & 516.55 \\
\hline & Spring & $230-2500$ & 950.83 & 1361.44 \\
\hline & Well & $6-1200$ & 427.86 & 590.04 \\
\hline Alkalinity & Natural tinaja & $42-1400$ & 135.64 & 173.46 \\
\hline \multirow[t]{4}{*}{$(500)$} & Modified tinaja & $62-520$ & 146.96 & 184.25 \\
\hline & Catchment & $42-1400$ & 133.08 & 205.18 \\
\hline & Spring & $210-780$ & 430.83 & 563.63 \\
\hline & Well & $120-270$ & 195.63 & 215.75 \\
\hline Arsenic & Natural tinaja & -1 & - & - \\
\hline \multirow[t]{4}{*}{$(0.5)$} & Modified tinaja & $0.00-0.10$ & 0.01 & 0.02 \\
\hline & Catchment & $0.00-0.07$ & 0.01 & 0.02 \\
\hline & Spring & $0.00-0.04$ & 0.01 & 0.02 \\
\hline & Well & $0.00-0.04$ & 0.003 & 0.01 \\
\hline Calcium & Natural tinaja & $19-219$ & 53.65 & 75.38 \\
\hline \multirow[t]{4}{*}{ (700) } & Modified tinaja & $17-88$ & 41.08 & 48.86 \\
\hline & Catchment & $17-67$ & 33.68 & 37.79 \\
\hline & Spring & $26-68$ & 46.67 & 56.40 \\
\hline & Well & $11-100$ & 38.63 & 51.90 \\
\hline Chloride & Natural tinaja & $6.80-410.00$ & 51.13 & 102.25 \\
\hline \multirow[t]{4}{*}{$(15000)$} & Modified tinaja & $7.50-83.00$ & 23.02 & 31.32 \\
\hline & Catchment & $5.60-360.00$ & 106.35 & 142.03 \\
\hline & Spring & $69.00-360.00$ & 134.83 & 191.17 \\
\hline & Well & $9.40-390.00$ & 96.18 & 161.98 \\
\hline Fluoride & Natural tinaja & - & - & - \\
\hline \multirow[t]{4}{*}{$(2.0)$} & Modified tinaja & $0.00-1.60$ & 0.06 & 0.20 \\
\hline & Catchment & $0.00-4.20$ & 1.20 & 1.79 \\
\hline & Spring & $0.00-2.70$ & 0.58 & 1.19 \\
\hline & Well & $0.00-7.10$ & 1.24 & 2.67 \\
\hline Iron & Natural tinaja & $0.00-1.17$ & 0.09 & 0.20 \\
\hline \multirow[t]{4}{*}{$(300)$} & Modified tinaja & $0.00-2.30$ & 0.23 & 0.44 \\
\hline & Catchment & $0.00-4.20$ & 0.20 & 0.44 \\
\hline & Spring & $0.00-0.49$ & 0.10 & 0.22 \\
\hline & Well & - & - & - \\
\hline Lead & Natural tinaja & - & - & - \\
\hline \multirow[t]{4}{*}{$(100)$} & Modified tinaja & - & - & - \\
\hline & Catchment & $0.00-0.01$ & .0001 & .0004 \\
\hline & Spring & - & - & - \\
\hline & Well & - & - & - \\
\hline Nitrate & Natural tinaja & $0.00-6.13$ & 0.69 & 1.40 \\
\hline \multirow[t]{4}{*}{$(100)$} & Modified tinaja & $0.00-2.80$ & 0.34 & 0.68 \\
\hline & Catchment & $0.00-5.30$ & 0.02 & 0.87 \\
\hline & Spring & $0.00-2.40$ & 0.46 & 1.00 \\
\hline & Well & $0.00-8.10$ & 1.78 & 3.27 \\
\hline
\end{tabular}

Table 1. Continued.

\begin{tabular}{|c|c|c|c|c|}
\hline $\begin{array}{l}\text { Parameter } \\
\text { (Guideline) }\end{array}$ & Water type & Range & Mean & $\begin{array}{l}\text { Upper } \\
95 \% \text { C }\end{array}$ \\
\hline Nitrite & Natural tinaja & $0.00-0.10$ & 0.01 & 0.02 \\
\hline \multirow[t]{4}{*}{$(10)$} & Modified tinaja & $0.00-1.90$ & 0.14 & 0.34 \\
\hline & Catchment & $0.00-0.10$ & .003 & 0.01 \\
\hline & Spring & - & - & - \\
\hline & Well & $0.00-0.64$ & 0.07 & 0.15 \\
\hline Sulfate & Natural tinaja & $0.00-573.00$ & 46.53 & 104.39 \\
\hline \multirow[t]{4}{*}{$(1000)$} & Modified tinaja & $0.00-54.00$ & 13.28 & 19.89 \\
\hline & Catchment & $0.00-250.00$ & 58.93 & 80.80 \\
\hline & Spring & $33.00-320.00$ & 118.33 & 174.63 \\
\hline & Well & $0.00-240.00$ & 27.48 & 109.40 \\
\hline Sulfide & Natural tinaja & $0.00-0.90$ & 0.17 & 0.33 \\
\hline \multirow[t]{4}{*}{$(25)$} & Modified tinaja & $0.00-3.50$ & 0.54 & 0.84 \\
\hline & Catchment & $0.00-2.00$ & 0.50 & 0.74 \\
\hline & Spring & $0.00-3.10$ & 0.82 & 1.46 \\
\hline & Well & $0.00-1.20$ & 0.24 & 0.46 \\
\hline Zinc & Natural tinaja & $0.00-0.27$ & 0.01 & 0.03 \\
\hline \multirow[t]{4}{*}{$(50)$} & Modified tinaja & - & - & - \\
\hline & Catchment & $0.00-0.49$ & 0.07 & 0.10 \\
\hline & Spring & $0.00-0.19$ & 0.02 & 0.06 \\
\hline & Well & $0.00-0.28$ & 0.08 & 0.13 \\
\hline
\end{tabular}

${ }^{1}$ Not detected.

wildlife populations. The results also suggest approaches to water development design and maintenance that can improve water quality. Newer designs of rainwater catchments have greater efficiency and typically do not require supplemental water (Lesicka and Hervert 1995). Reducing or eliminating water hauling will minimize inputs of dissolved salts, fluoride, and other groundwater constituents. When modifying natural tinajas, dams and gabion structures can be designed in a manner that allows flushing of accumulated organic matter and salts during runoff events (deVos and Clarkson 1990). For closed systems, troughs should be cleaned regularly. Removal of organic debris, algal mats, and accumulated sediments will decrease production of noxious decomposition products and make conditions less favorable for blooms of blue-green algae.

\section{ACKNOWLEDGMENTS}

Authors thank J. Kerns, V. Morrill, R. English, J. Hervert, R. Kearns, S. Henry, R. Varney, S. Obregon, N. Andrew, G. Mulcahy, A. Pauli, W. Castle, and M. Martin for assistance with various aspects of the project.

\section{LITERATURE CITED}

Brown, D. E. [ed.]. 1994. Biotic communities: Southwestern United States and northwestern Mexico. Salt Lake City, UT: University of Utah Press. 431 p.

BROYLES, B. 1995. Desert wildlife water developments: questioning use in the Southwest. Wildlife Society Bulletin 23:663-675.

Clesceri, L. S., A. E. Greenberg, and A. D. Eaton [Eds.]. 1998. Standard methods for the examination of water and wastewater. 20th ed. Washington, DC: American Public Health Association. 1325 p.

Codd, G. A., AND S. G. BelL. 1985. Eutrophication and toxic cyanobacteria in freshwaters. Water Pollution Control 84:225-232. 
deVos, J. C., JR., AND R. W. Clarkson. 1990. A historic review of Arizona's water developments with discussions on benefits to wildlife, water quality and design considerations. In: G. K. Tsukamoto and S. J. Stiver [EDS.]. Proceedings of the Wildlife Water Development Symposium; 29 November-1 December 1988; Reno, NV. Reno, NV: Nevada Chapter of The Wildlife Society and Nevada Department of Wildlife. $p$ 157-165.

Flechtner, V. R., J. R. Johansen, and W. H. Clark. 1998. Algal composition of microbiotic crusts from the central desert of Baja California, Mexico. Great Basin Naturalist 58:295-311.

GunN, J. 1990. Arizona's standard rainwater catchment. In: G. K. Tsukamoto and S. J. Stiver [EDS.]. Proceedings of the Wildlife Water Development Symposium; 29 November-1 December 1988; Reno, NV. Reno, NV: Nevada Chapter of The Wildlife Society and Nevada Department of Wildlife. p 19-24.

Halloran, A. F., and 0. V. Deming. 1958. Water development for desert bighorn sheep. Journal of Wildlife Management 22:1-9.

Hedlund, C. A. 1996. Trichomonas gallinae in avian populations in urban Tucson, Arizona [thesis]. Tucson, AZ: University of Arizona. $61 \mathrm{p}$.

Kocan, R. M. 1969. Various grains and liquid as potential vehicles of transmission for Trichomonas gallinae. Bulletin of the Wildlife Disease Association 5: 148-149.

Kubly, D. M. 1990. Limnological features of desert mountain rock pools. In: G. K. Tsukamoto and S. J. Stiver [EDS.]. Proceedings of the Wildlife Water Development Symposium; 29 November-1 December 1988; Reno, NV. Reno, NV: Nevada Chapter of The Wildlife Society and Nevada Department of Wildlife. $p$ 103-120.

LesiCKA, L. M., AND J. J. HeRvert. 1995. Low maintenance water development for arid environments: concepts, materials, and techniques. In: D. P. Young, R. Vinzant, and M. D. Strickland [EDS.]. Proceedings of the 2nd Wildlife Water Symposium; 27-28 April 1994; Laramie, WY. Laramie, WY: Water for Wildlife Foundation. p 52-57.

Peterson, H. G. 1999. Livestock and water quality. Agriculture and Agri-Food
Canada, Prairie Farm Rehabilitation Administration. Available at: http:// www.agr.gc.ca/pfra/water/livestck_e.htm. Accessed 16 May 2004.

Pybus, M. J., D. P. Hobson, And D. K. Onderka. 1986. Mass mortality of bats due to probable blue-green algal toxicity. Journal of Wildlife Diseases 22:449-450.

Ressom, R., F. S. Soong, J. Gitzgerald, L. Turczynowicz, 0. El Saad, R. Roder, T. Maynard, and I. Falconer. 1994. Health effects of toxic cyanobacteria (bluegreen algae). Canberra, Australia: National Health and Medical Research Council. 108 p.

Rosenstock, S. S., W. B. Ballard, and J. C. deVos, JR. 1999. Viewpoint: benefits and impacts of wildlife water developments. Journal of Range Management 52:302-311.

Schaefer, R. L., W. Mendenhall, and L. Ott. 1979. Elementary survey sampling. North Scituate, MA: Duxbury Press. 278 p.

Schmidt, S. L., and S. DeStefano. 1999. Use of water developments by nongame wildlife in the Sonoran Desert of Arizona. Tucson, AZ: University of Arizona Cooperative Fish and Wildlife Research Unit. $111 \mathrm{p}$.

Schwimmer, M., AND D. Schwimmer. 1968. Medical aspects of phycology. In: D. F. Jackson [ed.]. Algae, man, and the environment. Syracuse, NY: Syracuse University Press. p 279-358.

Shephard, W. D., D. W. Blinn, R. J. Hoffman, and P. T. Kantz. 2000. Algae of Devil's Hole, Death Valley National Park. Western North American Naturalist 60: 410-419.

Shelds, L. M., and F. Drouet. 1962. Distribution of terrestrial algae within the Nevada Test Site. American Journal of Botany 49:437-456.

Werner, W. E. 1985. Philosophies of water development for bighorn sheep in southwestern Arizona. Desert Bighorn Council Transactions 29:13-14.

Western Regional Climate Center. 2004. Historical climate information. Available at: http://www.wrcc.dri.edu/NEWWEB.html. Accessed 16 May 2004.

WriGHT, J. T. 1959. Desert wildlife: A research study. Wildlife Bulletin No. 6. Phoenix, AZ: Arizona Game and Fish Department. 112 p. 